\title{
$\checkmark$ Research Square \\ Utilization of Biotechnology, Neurotransmitter and Cytogenetic Indices in Selecting Pigeon Breeds
}

\section{Dr.Mohammed El-Sayed ( $\nabla$ m.a.el_sayed@outlook.com )}

National Gene Bank, Agricultural Research Center, Giza

N. S. Ibrahim

Egyptian Atomic Energy Authority

Heba A.E.M. Assi

Agricultural Research Center

\section{Mona E. Abdel Gwwad}

National Gene Bank, Agricultural Research Center, Giza

\section{W. S. Fouad}

Al-Azhar University

M. A. Ibrahim

National Gene Bank, Agricultural Research Center, Giza

Noura Atia

Egyptian Atomic Energy Authority

Abdel-Moneim E. Abdel-Moneim

Egyptian Atomic Energy Authority

\section{Research Article}

Keywords: LDH-A and DR-D4 gene, neurotransmitters, cytogenetic indices, racing pigeons, wild rock pigeons

Posted Date: October 1st, 2021

DOl: https://doi.org/10.21203/rs.3.rs-916449/v1

License: (9) This work is licensed under a Creative Commons Attribution 4.0 International License.

Read Full License 


\title{
Utilization of biotechnology, neurotransmitter and cytogenetic indices in selecting pigeon breeds
}

\author{
Noura Atia $^{3}$ and Abdel-Moneim E. Abdel-Moneim ${ }^{3}$ \\ 1. Animal Genetic Resources dept., National Gene Bank, Agricultural Research Center, Egypt \\ 2. Animal Production Research Institute, Agricultural Research Center, Giza, Egypt. \\ 3. Biological Applic. dept., Nuclear Res. Center, Egyptian Atomic Energy Authority, P.O. Box 13759, Egypt \\ 4. Biotechnology dept., Faculty of Agriculture, Al-Azhar University, Nasr city, Egypt. \\ *Corresponding author: M. A. El-Sayed \\ Emails: m.a.el sayed@outlook.com; \\ mohammed.el-Sayed@arc.sci.eg
}

M. A. El-Sayed ${ }^{1}$, N.S. Ibrahim ${ }^{3}$, Heba A.E.M. Assi ${ }^{2}$, Mona E. Abdel Gwwad ${ }^{1}$, Waleed S. Mohammed ${ }^{4}$, M.A.Ibrahim ${ }^{1}$,

\begin{abstract}
The DNA polymorphism LDH-A and DRD4 gene, some neurotransmitter and cytogenetic indices of three sexed pigeon breeds; non-racing pigeons (wild rock), racing long and short distances pigeons (e.g: Gan aarden) and (e.g: Gansen) have been performed. The long-distance pigeon demonstrated the highest levels of neurotransmitters in brain tissues. Long distance male pigeons have a unique LDH-A polymorphism, so A changed to $\mathrm{G}$, which means that changes in gene expression resulted in differences in amino acid structure $\mathrm{K}(\mathrm{lys})$ was converted to $\mathrm{E}(\mathrm{glu})$ in the LDH-A gene only in long distance male pigeons compared to other breeds. In addition to this, the DRD4 polymorphism of long distance male pigeons in which $\mathrm{A}$ changed to $\mathrm{C}$ and $\mathrm{A}$ changed to $\mathrm{T}$ indicates the presence of a unique diversity in this breed. This means that changes in gene expression resulted in overall amino acid structure differences only in long distance male pigeons when compared to other breeds, where $\mathrm{R}(\arg )$ and $\mathrm{L}($ leu $)$ were converted to $\mathrm{S}$ (ser) and $\mathrm{F}$ (phe). Neurotransmitters are synthesised in the body from these amino acids. It concluded that measurements would be useful indices for the differentiation, genetic characterization, provide a foundation for conservation programs of the breeding and selecting racing pigeon breeders.
\end{abstract}

Keyword: LDH-A and DR-D4 gene, neurotransmitters, cytogenetic indices, racing pigeons, wild rock pigeons.

\section{INTRODUCTION}

It is several hundred different pigeon breeds have been established, In the domestication of the wild rock pigeon (Columba livia), hundreds of years ago, most breeds are descended exclusively because of their appearance and acrobatic abilities called "fancy pigeon" as Nemthawy pigeon, or for reproduction purposes, bred originally for meat source in form of squabs or fledged juvenile pigeons as Romani and King pigeons, and at last for flying /sporting capabilities bred mainly for flying game and racing purposes, named "Zagel pigeon" (1 and 2). Probably the most common use for the domesticated pigeon today is pigeon racing, a sport that is popular in virtually every country in the world, due to the unique ability of homing pigeons to fly and return back to their loft from huge distances and at such speeds, therefore, these unique birds can compete on the basis of their characteristics and performance in the greatest competitions race "a global sport of pigeon racing" in Olympic games either for a short distance up to 300 miles or for long-distance about 600 miles to win large sums of prize money up to $\$ 1$ million 
when the pigeons return home fastest from a long race (3,4 and 5). It is a rich industry with stud pigeons and race winners fetching huge sums of money e.g., one racing pigeon named "Armando", the champion racing pigeon that took first place in one of the biggest races in Europe has been sold for \$1.4 million in an online auction by a mysterious buyer in China. Another pigeon called "Playboy" won the 620-mile Barcelona race in 2008, has recently been purchased from its Belgian owner, Mr Van Roy, by a Japanese businessman, for a record $\$ 144,000$. Hence, the pigeon fanciers over the world give great attention to having good pigeon as breeding stock with a top of the line pedigree in performance in order to build a successful pigeon racing career and produce the best long-distance racer pigeon that can win races of all time, thus, racing pigeons have been selectively bred to find their way home quickly over what are often extremely long distances. Therefore, a better understanding of the genetic background of racing performance in the pigeon, especially the identification of genetic markers for this trait, might be useful for selecting breeding stock for further progress in pigeon racing, and determine the abilities of bird to fly either short distances range from 100 to $600 \mathrm{~km}$ or fly extremely long distances up to 1000 $\mathrm{km}$. A few articles have been published on the pigeon racing industry and pigeon selection. Therefore, in this respect, there are a hundred genes that contribute to the success of the racing pigeon performance. The values of the DNA polymorphism LDH-A and DR-D4 gene, neurotransmitter and cytogenetic indices in non-racing wild rock pigeon, racing long distances, or short distances pigeons could provide or support an objective assessment of the body health status or associated with flying performance and spatial orientation and could be important source of information with valuable selection meaning. The lactate dehydrogenase A (LDH-A) is one of the genes named "performance -associated gene" and found predominantly in muscle tissues. It considers the most important genes that are responsible for both the synthesis and recycling of lactic acid in the muscles (6 and 7), the presence of LDH-A gene enable the body muscles to utilizes the cumulated lactate which produced during the high physical effort of racing pigeon in the race and turn it into positive energy for mitochondrial respiration in skeletal muscle, allowing the bird to fly longer with speed and high-performance during the marathon racing $(8,9,10$ and 11). Dopamine receptors D4 (DR-D4) also, is another important gene named "neurotransmitterassociated gene "that known to be associated with pigeon racing performance (12 and 13). Hence, the presence of the dopamine gene in pigeon breed provide stimulation/depression to the nervous system and causes the brain to produce, reabsorb, or transmit higher dopamine resulting in a better muscle performance. The positive correlation between the presence degree of dopamine related gene in the pigeon breed and dopamine concentration confirms the vital role of neurotransmitter in brain functions. Hence, the brain needs neurotransmitters to regulate many necessary functions, including muscle movement, heart rate, mood, concentration, breathing, appetite, sleep cycles and digestion. Thus, it is important to study the neurotransmitter status in the racing pigeon's brain as a valuable index in the selection of pigeon breeds. The neurotransmitters are called powerful neurochemicals produced by activating neuron cells in the brain and influence synaptic activity, transmit signals from nerve cells to target cells, such as muscles, glands, or other nerves. In this respect, dopamine (DA), is a neurotransmitter, one of the brain's chemical messengers, used to send signals of pleasure and stimulates the growth hormone secretion. It is also involved in learning, memory formation, muscle movement and coordination abilities, and attention functions (14). Gamma-aminobutyric acid (GABA), also, is a mood regulator. It has an inhibitory action in the central nervous system, essential for the memory-storage elements of the brain, vision, lowers stress and anxiety (15). While Serotonin (ST), is an inhibitory neurotransmitter present in the brain and other tissues, important factor in sleep cycle, helps regulate mood and emotions, appetite, gut motility, blood clotting, pain, body temperature, the body's circadian rhythm, cardiovascular function and plays a role in depression and anxiety (16). Acetylcholine esterase (ACHE), is an excitatory neurotransmitter, critical for normal attention, memory, sleep cycle, stimulates 
muscle contraction. A balance of neurotransmitters is necessary to prevent certain health conditions, such as depression, anxiety and neurological disorders (17). In addition, melatonine (MTN) is a neuromodulator, involved with the regulation of circadian rhythm, regulates various physiological processes, such as sleep wake cycle, seasonal adaptation, neuroendocrine function, thermoregulation, feeding patterns and immune function (18 and 19). On the other side of this study cytogenetic diversity within different species helps delineate evolutionary genetic relationships. Characterization of chromosomes by simple, rapid and reliable approaches is one of the main goals of Gene banks. In this regard, the classical banding techniques are still the most used procedures since they represent standard and well established karyotyping methods. This is particularly true for bird populations, whose routine cytogenetic analysis has been performed mainly by the application of classical methods. The chromosomes in different organisms as well as in the same cell besides their absolute and relative sizes may show a definite individuality in their genomic pattern as are evident from their size, shape, position of centromere and in such additional features as secondary construction and satellites. In addition the study of chromosome structure and the precise identification of chromosomes using differential staining techniques such as Gbanding establishing a standard chromosome nomenclature for each breed. There are few or no data published about the LDH-A and DR-D4 gene polymorphism, neurotransmitter and cytogenetic indices for racing pigeon breeds. Therefore, the present study aimed to compare the values of DNA polymorphism LDH-A and DR-D4 gene, a number of neurotransmitters concentrations includes: dopamine, serotonin, gamma-aminobutyric acid, acetylcholine esterase and melatonin and cytogenetic indices of clinically healthy individuals of the non- racing wild rock pigeon, racing long distances, and racing short distances pigeons.

\section{METHODS}

\section{Pigeon breeds source and care}

Three sexually mature pigeon breeds (racing long distances pigeons e.g. Gan aarden breed, racing short distances pigeons e.g. Gansen breed and non-racing wild rock pigeons), were obtained from Egy-Nash pigeon housed loft of Nasr City, Cairo, Egypt. Thirty birds were used in this study for biotechnology, neurotransmitter and cytogenetic estimations. Six adult pigeons of known gender, weighing 400-520 g were used in this part of study The birds in Egy-Nash pigeon loft were maintained under the same management conditions of diet, grit, water, metal cages and 12:12 hour light-dark cycle.

Statement on adherence to relevant ethical guidelines for experimenting on animals.

Adult specimens of pigeon breeds $(n=30$, bodyweight $660 \pm 50 \mathrm{~g}$, mean \pm SD) including non-racing pigeons, (wild rock), racing long distances pigeons (e.g: gan aarden), and racing short distances pigeons (e.g: gansen) were collected from the Egy-Nash pigeon housed loft of Nasr city between November 2020 and May 2021. The experiments in the present study were conducted in accordance with the principles and procedures that were approved by the scientific and ethics committee of local experimental animal care of the biological application department, Egyptian nuclear research center (Approved number 203; date of approval: 10 March 2021), according to the guidelines the Institutional animal care and use committee in Egypt (45) and were in accordance with the European Guidelines (2010/63/EU). All procedures in studies involving animals were performed in compliance with The ARRIVE guidelines 2.0 (Animal Research: Reporting In Vivo Experiments) (46). Our research was following the ethical principles of the 3Rs replacement, reduction, and refinement- in the design of animal studies to minimize any pain or distress to animals. 


\section{Collection of data}

Three estimations were performed on pigeon breeds as follows:

\section{1-Genetic analysis}

The genes were selected according to (8 and 20). Genes, primer sequences, and references are as shown in table (1). Blood samples were obtained once from each pigeon breed $(n=30)$ for genomic DNA extraction, isolation and purification according to methods described by (21) as follows: a half milliliter of the blood sample was withdrawn from the wing vein on EDTA tube as anti-coagulant ( $0.2 \mathrm{ml}$ of $0.5 \mathrm{M}$ EDTA). DNA was freshly extracted from the whole collected EDTA-blood. Three milliliter of lysis buffer TSTM ( $20 \mathrm{mM}$ Tris- $\mathrm{HCl} \mathrm{pH} 7.6,640 \mathrm{mM}$ sucrose, $2 \%$ Triton $\mathrm{X}-100,10 \mathrm{mM} \mathrm{MgCl} 2$ ) was added to the aliquot. The mixture was centrifuged, and the pellet was suspended in $150 \mu$ proteinase $\mathrm{K}, 1.5 \mathrm{ml}$ nuclei lysis buffer, and $110 \mu \mathrm{l}$ SDS $20 \%$. After overnight incubation at $37^{\circ} \mathrm{C}$, the proteins were removed by $\mathrm{NaCl} 6 \mathrm{M}$, and the DNA was precipitated by ice-cold absolute ethanol.

\begin{tabular}{lll}
\multicolumn{2}{l}{ Table (1). Primer sequence according to the following: } & \\
\hline Genes & Primers sequences & References \\
\hline DR-D4 Fragment (1) & F: TTTGGGATCGCTCGCTTACC & 20 \\
& R: ATGACAGGGGATGCTACAGC & 20 \\
\hline DR-D4 Fragment (2) & $\begin{array}{l}\text { F: TTTGGGATCGCTCGCTTACC } \\
\text { R: GCAGGACAACACAGCGTCTC }\end{array}$ \\
\hline DR-D4 Fragment (3) & $\begin{array}{l}\text { F: GGGCCAACAGGAAGCTCTAT } \\
\text { R: GCAGGACAACACAGCGTCTC }\end{array}$ \\
\hline LDH-A & F: ATCATGGGCTATTGGCCTCT & 20 \\
& R: AAAACCTGAGGAAGAGGA CAAA
\end{tabular}

\section{PCR Reaction}

\section{LDH-A and DR-D4 gene}

The PCR reaction mixture contained approximately $80 \mathrm{ng}$ of genomic DNA, 10 pmol of each primer, $25 \mu \mathrm{L}$ of master mix in a total volume of $50 \mu \mathrm{L}$. The following cycles were applied: denaturation at $95^{\circ} \mathrm{C}$ for $5 \mathrm{~min}$, followed by 35 cycles at $95^{\circ} \mathrm{C}$ for $60 \mathrm{~s}$, primer annealing at 57 and $60^{\circ} \mathrm{C}$ for $30 \mathrm{~s}$, and PCR products synthesis at $72^{\circ} \mathrm{C}$ for $60 \mathrm{~s}$, and then final synthesis at $72^{\circ} \mathrm{C}$ for $10 \mathrm{~min}$.

The LDH-A and DR-D4 genes were directly purified by Gene JET PCR purification kit and sequenced on ABI3730XL DNA Analyzer apparatus throughout sigma Company. The sequenced fragments were alignment using http://ncbi.nlm.nih.gov/BLAST/ with the published data in the NCBI databases (nonredundant nucleotide database) and submitted to the Gene Bank using Bank It tool: http://www.ncbi.nlm.nih.gov/BankIt/ and The EMBL-EBI search and sequence analysis tools APIs by (22). Finch TV 1.4.0 (http://www.geospiza.com/finchtv/) .CLC Sequence Viewer Version 6.8.2 www.clcbio.com and MEGA-6 using in alignment with three genotypes.

\section{2- Karyotype Analysis}

Preparation of bone marrow metaphase chromosome using technique described by (23) minor modifications. Twenty cells of well-spread mitotic metaphase plates were used for chromosome measurements. The length of short arm (p) and the long arm (q) of each chromosome were measured the chromosomes 1 to 8 and as well as sex chromosome $\mathrm{Z}$ and $\mathrm{W}$, the total length (TL) was calculated as (p $+q)$. According to the formula ((TL/sum TL) x100), the relative length (RL percent) of each chromosome was 
calculated as a percentage of the overall length of the complement. The centromeric index (CI percent) was calculated using the formula ( $\mathrm{p} / \mathrm{TL}) \mathrm{x} 100)$.

\section{GTG-banding technique}

The GTG-banding technique was applied on the metaphase chromosomes of the pigeon breeds under investigation. The GTG-banding technique was adopted from (24). The slides were dried on air and then soaked in working trypsin $(0.025 \%$ trypsin EDTA) at $37 \mathrm{oC}$ until the termination of trypsin activity (5 to 10 seconds) by washing the slide with phosphate buffer. The trypsinized slides were stained with $20 \%$ Giemsa solution for 30 minutes. The pattern of $\mathrm{G}$ bands was determined on the basis of an analysis of 1600 chromosomes obtained from 20 metaphase plates. The description of chromosome morphology and classification was done following (25). According to the standard of $G$ band identification on the chromosomes of Gallus domesticus (26).

\section{Microscope examination, karyotyping and idiograming}

Chromosomes examination was performed using a vertical fluorescence microscope (Leica DM4 B) equipped with a cooled digital color camera (Leica DFC450 C). Twenty cells with clearly observable and well spread chromosomes of each bird were examined and photographed at $100 \times$ magnification under oil immersion. Chromosome counting and karyotyping were performed using the automated karyotyping \& FISH software processing (Leica CW4000) system. Idiograms were constructed from complete chromosomes, which showed the maximum possible banding patterns in at least ten different metaphase plates.

\section{3-Brain's neurotransmitters assay}

Ten adult healthy birds, 12 months age old, 450-550 g body weight, from each pigeon breed were sacrificed, decapitated and whole brains tissue were dissected out from the skull. All brain samplings were done at 9:00 a.m. to remove circadian variations in concentrations and rapidly frozen immediately in liquid nitrogen gas for neurotransmitters concentrations assay include: dopamine (DA), serotonin (ST), gamma-aminobutyric acid (GABA), acetyl choline esterase (ACHE) and melatonin (MTN) according to (27) method, described as following: wet tissue was weighed and homogenized in $\mathrm{HCl}-$ butanol for about 1 minute (in 1:10 ratio). The sample was then centrifuged for 10 minutes at $3000 \mathrm{rpm}$. An aliquot supernatant phase $(1 \mathrm{ml})$ was removed and added to centrifuge tube containing $2.5 \mathrm{ml}$ hexane and $0.3 \mathrm{ml}$ of $0.1 \mathrm{M} \mathrm{HCl}$. The aqueous phase $(0.2 \mathrm{ml})$ was then taken for dopamine assay. All steps were carried out at $00 \mathrm{C}$ (on ice). To the $0.2 \mathrm{ml}$ of aqueous phase, $0.05 \mathrm{ml}$ of $0.4 \mathrm{M} \mathrm{HCl}$ and $0.1 \mathrm{ml}$ of sodium acetate buffer ( $\mathrm{pH}$ 6.9) were added, and then $0.1 \mathrm{ml}$ of iodine solution ( $0.1 \mathrm{M}$ in ethanol) was added for oxidation.The reaction was stopped after $2 \mathrm{~min}$ by addition of $0.1 \mathrm{ml}$ sodium sulphite solution. $0.1 \mathrm{ml}$ acetic acid is added after 1.5 minutes. The solution was then heated to $100^{\circ} \mathrm{C}$ for 6 minutes. When the sample again reached room temperature, excitation and emission spectra were read from the spectrofluorimeter at 330-375 nm. Tissue blanks for dopamine (DA), serotonin (ST), gammaaminobutyric acid (GABA), acetyl choline esterase (ACHE) and melatonin (MTN)were prepared by adding the reagents of the oxidation step in reversed order (sodium sulphite before iodine).

\section{Calculation}

The following formula is used to calculate the neurotransmitter level.

$$
X \text { neurotransmitter }=\frac{\text { Sample O.D }- \text { Blank O.D }}{\text { Standard O.D }- \text { Blank O.D }} \text { X Conc. Of Standard }(500 \mathrm{pg} / \mathrm{ml})
$$


This gave the amount of neurotransmeter present in $1 \mathrm{ml}$ of the sample. The final reading of GABA, ACHE and MTN neurotransmitter levels are expressed as: pg/ml. While, dopamine DA, and serotonin (ST), concentrations were measured by radioimmunoassay with a kit which was produced by the Institute of Isotopes Co., Ltd. (Budapest, Hungary), and the samples were counted on Packard Gamma Counter (PerkinElmer Inc., Branford, CT, USA). The final reading of DA, and ST, neurotransmitter levels are expressed as: $\mathrm{ng} / \mathrm{ml}$.

\section{Statistical analysis}

All the neurotransmetres data were analyzed with the general linear model and variance procedure analysis between pigeon breeds using the statistical software (28). At a significance level of 5\%, Tukey's technique for multiple comparison tests was performed to discover significant variations in data.

\section{RESULTS}

\section{LDH-A gene polymorphism}

Eleven polymorphic sites have been identified in LDH-A gene among three sexed pigeon breeds expressed as long distances racing, short distances racing and wild rock pigeons as showed in Table 2. The polymorphism of long distances male pigeon was $5 \mathrm{bp}$ variation/deletion resulting in five positions length; 195bp, 385bp, 386bp, 387bp and 389bp (GenBank accession no: MW044915), while, the polymorphism of long distances female pigeon (GenBank accession no: MW044598), and in both gender of short distances racing pigeon(GenBank accession no: MW072293 for female), (GenBank accession no: MW072294 for male) were 3bp deletion and resulting in the same three positions length; $20 \mathrm{bp}, 362 \mathrm{bp}$ and 366bp. Furthermore, the polymorphism of wild rock female pigeons was $7 \mathrm{bp}$ variation/deletion resulting in seven positions length; 20bp, 362bp, 366bp, 383bp, 386bp, 387bp and 388bp (GenBank accession no: MW039603), while, the polymorphism of male wild rock pigeons was $4 \mathrm{bp}$ variation/deletion resulting in four positions length of 20bp, 261bp, 362bp and 366bp (GenBank accession no: MW044597). The obtained results on LDH-A gene polymorphism indicate the presence of different biodiversity values among the mention pigeon breeds particularly, between long distances male pigeon and both gender of wild rock pigeons wherein they showed high variation in LDH-A gene polymorphism values, while the rest of breeds showed the same LDH-A gene polymorphism. Furthermore, the genetic differentiation was evaluated using the nucleotide differentiation and the frequency of LDH-A gene, the analysis showed that the count of (A) nucleotides was ranged from 119 in long distances male pigeon to 117 in wild rock female pigeons. Also, the count of (T) nucleotides ranged from 114 in both gender of wild rock pigeons to 112 in long distances male pigeon. The count of (C) nucleotides ranged from 68 in wild rock male pigeons to 69 in the rest of other genotypes. While, the count values of $(\mathrm{G})$ were equal in all six genotypes. The lowest value was 154 with wild rock male pigeons in $(\mathrm{C}+\mathrm{G})$ while the highest value was recorded in $(\mathrm{A}+\mathrm{T})$. The highest frequency value $(0.601)$ was found in male wild rock pigeons (0.601), while the same frequency values $(0.598)$, were found in all genotypes as shown in Table 3.

In this part of study, the variations appeared in LDH-A polymorphism of long distances male pigeon, particularly on the position length $389 \mathrm{bp}$ indicate the presence of unique diversity in this breed, hence $A$ changed to $G$ which means that changes gene expression occurred for LDH-A gene resulted in the differences in amino acids structure. 


\section{DR-D4 gene polymorphism}

Six polymorphic locations have been discovered in the DR-D4 gene in three sexed pigeon breeds expressed as racing long distances, racing short distances and non-racing wild rock pigeons as showed in Table 2.

The polymorphism of long distances female pigeon was $1 \mathrm{bp}$ variation resulting in one position length; 17bp (GenBank accession no: MT982609). And, the long distances male pigeon polymorphism was $2 \mathrm{bp}$ variation resulting in two positions length of 418bp and 524bp (GenBank accession no: MT982610). Also, the short distances female pigeon polymorphism was $1 \mathrm{bp}$ variation resulting in one position length of 457bp (GenBank accession no: MT982612). And, the short distances male pigeon polymorphism was $2 \mathrm{bp}$ variation resulting in two positions length of $17 \mathrm{bp}$ and 496bp (GenBank accession no: MT982613). Finally, the wild rock female pigeon's polymorphism was 7bp (GenBank accession no: MT982611).

The obtained results in DR-D4 gene polymorphism indicate the presence of different biodiversity values among the mention pigeon breeds in particular, among long distances male pigeon and both gender of wild rock pigeons. Regarding the count of nucleotides and the frequency of DR-D4 gene, the analysis showed that the count of (A) nucleotides was ranged from 134 in long distances male pigeon to 135 in the other breeds. Also, the count of (T) nucleotides ranged from 130 with short distances male pigeon to 133 with short distances female pigeon and long distances male pigeon. The count of (C) nucleotides ranged from 194 with short distances female pigeon to 197 in short distances male pigeon. While, the count values of $(\mathrm{G})$ were equal in all five genotypes. The lowest value was 351 with short distances female pigeon in $(\mathrm{C}+\mathrm{G})$ while the highest value was recorded in $(\mathrm{A}+\mathrm{T})$. The frequency values varied from 0.567 with short distances female pigeon to 0.572 with short distances male pigeon in $(\mathrm{C}+\mathrm{G})$ while in $(\mathrm{A}+\mathrm{T})$ the frequency values varied from 428 with male racing pigeon's short distances to 0.433 with short distances female pigeon as shown in Table 3.

On the other side, the variations appeared in DR-D4 polymorphism of long distances male pigeon, particularly, on two positions length of 418bp and 524bp indicate the presence of unique diversity in this breed, hence $\mathrm{A}$ changed to $\mathrm{C}$ and $\mathrm{A}$ changed to $\mathrm{T}$, which means that changes in gene expression occurred for the DR-D4 gene resulted in overall differences in amino acids structure as shown in table 4.

\section{DR-D4 and LDH-A gene protein sequence}

The data derived from the LDH-A gene protein sequencing (CDs) region in the pigeon breeds as shown in Figure (1,A), showed that in the position of 60 the amino acid K (lys) was converted to $\mathrm{E}$ (glu) in the LDH-A gene only in long distances male pigeon compared to the other breeds. These amino acids consider a precursor in synthesis the neurotransmitters in all the body. The identical match scored among three pigeon breeds was $98 \%$, while, the conservation scored a total positive value of $2 \%$ in long distances male pigeon. Whereas, the amino acids E (glu) was scored $8.1 \%$ in long distances male pigeon , while in the other breeds scored $6.5 \%$ with LDH-A gene.

In addition, the CDs region of the DR-D4 gene in the pigeon breeds showed also that in the positions of 117 and 153 the amino acid R ( $\arg$ ) and L (leu) were converted to S (ser) and F (phe) only in long distances male pigeon compared to the other breeds as shown in Figure $(1, \mathrm{~B})$. These amino acids consider also a precursor in synthesis the neurotransmitters in all the body. The identical match scored among three pigeon breeds was $99 \%$. This means that the gap has been estimated of $1 \%$ for long 
distances male pigeon. Whereas, the amino acids of S (ser) and F (phe) were scored of 7.14 and $5 \%$ in long distances male pigeon, while in the other breeds scored of 6.6 and 4.4\% with DR-D4 gene.

Table (2) Counts of nucleotides of Dopamine Receptor D4 (DR-D4) and lactate dehydrogenase A (LDH-A) genes in three sexed breeds (racing long distances, short distances and non-racing wild rock pigeons).

\begin{tabular}{|c|c|c|c|c|c|c|c|c|c|c|c|c|c|}
\hline \multirow{3}{*}{ Breed } & \multirow{3}{*}{ Gender } & \multicolumn{12}{|c|}{ Counts of nucleotides } \\
\hline & & \multicolumn{6}{|c|}{ DR-D4 gene } & \multicolumn{6}{|c|}{ LDH-A gene } \\
\hline & & $\mathbf{A}$ & $\mathbf{T}$ & C & G & $\mathbf{C}+\mathbf{G}$ & $\mathbf{A}+\mathbf{T}$ & $\mathbf{A}$ & $\mathbf{T}$ & $\mathbf{C}$ & G & $\mathbf{C}+\mathbf{G}$ & A+T \\
\hline \multirow{2}{*}{$\begin{array}{lll}\text { Racing } & \text { long } & \text { distances } \\
\text { pigeon } & & \end{array}$} & Female & 135 & 131 & 196 & 157 & 353 & 266 & 118 & 113 & 69 & 86 & 155 & 231 \\
\hline & Male & 135 & 132 & 195 & 157 & 352 & 267 & 119 & 112 & 69 & 86 & 155 & 231 \\
\hline \multirow{2}{*}{$\begin{array}{l}\text { Racing short distances } \\
\text { pigeon }\end{array}$} & Female & 135 & 133 & 194 & 157 & 351 & 268 & 118 & 113 & 69 & 86 & 155 & 231 \\
\hline & Male & 135 & 130 & 197 & 157 & 354 & 265 & 118 & 113 & 69 & 86 & 155 & 231 \\
\hline \multirow{2}{*}{$\begin{array}{l}\text { Non-racing wild rock } \\
\text { pigeon }\end{array}$} & Female & 134 & 133 & 195 & 157 & 352 & 267 & 117 & 114 & 69 & 86 & 155 & 231 \\
\hline & Male & 134 & 133 & 196 & 157 & 352 & 267 & 118 & 114 & 68 & 86 & 154 & 232 \\
\hline Total & & 808 & 792 & 1173 & 942 & 1762 & 1333 & 708 & 679 & 413 & 516 & 929 & 1387 \\
\hline
\end{tabular}

Table (3) Frequencies of Dopamine Receptor D4 (DR-D4) and lactate dehydrogenase A (LDH-A) genes in three sexed breeds (racing long distances, short distances and non-racing wild rock pigeons).

\begin{tabular}{|c|c|c|c|c|c|}
\hline \multirow{2}{*}{ Pigeon Breeds } & \multirow{2}{*}{ Gender } & \multirow{2}{*}{ Genes } & \multicolumn{3}{|c|}{ Frequencies of nucleotides } \\
\hline & & & G/C & $\mathbf{A} / \mathbf{T}$ & PIC \\
\hline \multirow{4}{*}{ Racing long distances pigeon } & \multirow{2}{*}{ Female } & LDH-A & 0.402 & 0.598 & 0.48 \\
\hline & & DR-D4 & 0.570 & 0.430 & 0.49 \\
\hline & \multirow{2}{*}{ Male } & LDH-A & 0.402 & 0.598 & 0.48 \\
\hline & & DR-D4 & 0.569 & 0.431 & 0.49 \\
\hline \multirow{4}{*}{ Racing short distances pigeon } & \multirow{2}{*}{ Female } & LDH-A & 0.402 & 0.598 & 0.48 \\
\hline & & DR-D4 & 0.567 & 0.433 & 0.49 \\
\hline & \multirow{2}{*}{ Male } & LDH-A & 0.402 & 0.598 & 0.48 \\
\hline & & DR-D4 & 0.572 & 0.428 & 0.49 \\
\hline \multirow{4}{*}{ Non-racing wild rock pigeon } & \multirow{2}{*}{ Female } & LDH-A & 0.402 & 0.598 & 0.48 \\
\hline & & DR-D4 & 0.569 & 0.431 & 0.49 \\
\hline & \multirow{2}{*}{ Male } & LDH-A & 0.399 & 0.601 & 0.48 \\
\hline & & DR-D4 & 0.402 & 0.598 & 0.48 \\
\hline
\end{tabular}

Table (4). Deletion and variation in positions of lactate dehydrogenase A (LDH-A) and Dopamine Receptor D4 (DR-D4) genes in three sexed breeds (racing long distances, short distances and non-racing wild rock pigeons).

\begin{tabular}{|c|c|c|c|c|c|c|}
\hline \multirow[t]{2}{*}{ Genes /Breed } & \multicolumn{3}{|c|}{ Female racing long distances pigeon } & \multicolumn{3}{|c|}{ Male racing long distances pigeon } \\
\hline & Position (bp) & Deletion & Variation & Position (bp) & Deletion & Variation \\
\hline LDH-A & 20 & A & & 195 & & $\mathrm{~T} \rightarrow \mathrm{A}$ \\
\hline LDH-A & 362 & A & & 385 & $\mathrm{C}$ & \\
\hline LDH-A & 366 & $\mathrm{C}$ & & 386 & A & \\
\hline LDH-A & & & & 387 & G & \\
\hline LDH-A & & & & 389 & & $\mathrm{~A} \rightarrow \mathrm{G}$ \\
\hline DR-D4 & 17 & & $\mathrm{~T} \rightarrow \mathrm{C}$ & 418 & & $\mathrm{~A} \rightarrow \mathrm{C}$ \\
\hline \multirow[t]{3}{*}{ DR-D4 } & & & & 524 & & $\mathrm{C} \rightarrow \mathrm{T}$ \\
\hline & \multicolumn{3}{|c|}{ Female racing short distances pigeon } & \multicolumn{3}{|c|}{ Male racing short distances pigeon } \\
\hline & Position (bp) & Deletion & Variation & Position (bp) & Deletion & Variation \\
\hline LDH-A & 20 & A & & 20 & A & \\
\hline LDH-A & 362 & A & & 362 & A & \\
\hline LDH-A & 366 & $\mathrm{C}$ & & 366 & $\mathrm{C}$ & \\
\hline DR-D4 & 457 & & $\mathrm{C} \rightarrow \mathrm{T}$ & 17 & & $\mathrm{~T} \rightarrow \mathrm{C}$ \\
\hline DR-D4 & & & & 496 & & $\mathrm{~T} \rightarrow \mathrm{C}$ \\
\hline
\end{tabular}




\begin{tabular}{lllllll}
\hline & \multicolumn{3}{l}{ Female non-racing wild rock pigeon } & \multicolumn{4}{l}{ Male non-racing wild rock pigeon pigeon } \\
\hline & Position (bp) & Deletion & Variation & Position $(\mathbf{b p})$ & Deletion & Variation \\
\hline LDH-A & 20 & $\mathrm{~A}$ & & 20 & $\mathrm{~A}$ & \\
\hline LDH-A & 362 & $\mathrm{~A}$ & & 261 & $\mathrm{~A}$ & $\mathrm{C} \rightarrow \mathrm{T}$ \\
\hline LDH-A & 366 & $\mathrm{C}$ & & 362 & $\mathrm{C}$ & \\
\hline LDH-A & 383 & & $\mathrm{C} \rightarrow \mathrm{T}$ & 366 & & \\
\hline LDH-A & 386 & $\mathrm{~A} \rightarrow \mathrm{C}$ & & & \\
\hline LDH-A & 387 & & $\mathrm{G} \rightarrow \mathrm{A}$ & & & \\
\hline LDH-A & 388 & & $\mathrm{~A} \rightarrow \mathrm{G}$ & & & \\
\hline
\end{tabular}

\begin{tabular}{|c|c|c|c|}
\hline SM & \multicolumn{2}{|r|}{ VADLAETIMKNLRRVHPISTVVKGMHGIKEDVFLSVPCVLGSSGITDVVKMILKPEEEDK } & 60 \\
\hline SF & \multicolumn{2}{|c|}{ VADLAETIMKNLRRVHPISTVVKGMHGIKEDVFLSVPCVLGSSGITDVVKMILKPEEEDK } & 60 \\
\hline WF & \multicolumn{2}{|r|}{ VADLAETIMKNLRRVHPISTVVKGMHGIKEDVFLSVPCVLGSSGITDVVKMILKPEEEDK } & 60 \\
\hline LF & \multicolumn{2}{|r|}{ VADLAETIMKNLRRVHPISTVVKGMHGIKEDVFLSVPCVLGSSGITDVVKMILKPEEEDK } & 60 \\
\hline WM & \multicolumn{2}{|r|}{ VADLAETIMKNLRRVHPISTVWKGMHGIKEDVFLSVPCVLGSSGITDVVKMILKPEEEDK } & 60 \\
\hline LM & \multicolumn{2}{|c|}{ 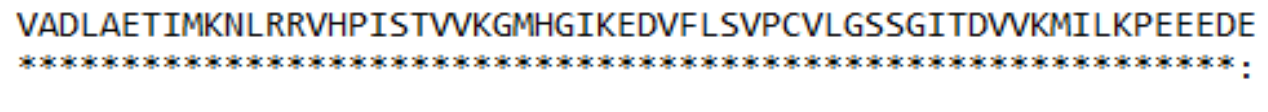 } & 60 \\
\hline SM & LR & 62 & \\
\hline SF & LR & 62 & \\
\hline WF & LR & 62 & \\
\hline LF & LR & 62 & \\
\hline WM & LR & 62 & \\
\hline \multirow[t]{2}{*}{ LM } & LR & 62 & \\
\hline & ** & & \\
\hline $\begin{array}{l}\text { Fig. } \\
\text { raci }\end{array}$ & & quences of the three sexed pigeon breeds (racing long distances, short distar & \\
\hline
\end{tabular}




\begin{tabular}{|c|c|c|}
\hline LF & FIAVSIPLNYNRRQIDLRQLILISTTWIFAFAVASPVIFGLNNVPNRDPSLCQLEDDNYI & 60 \\
\hline SM & FIAVSIPLNYNRRQIDLRQLILISTTWIFAFAVASPVIFGLNNVPNRDPSLCQLEDDNYI & 60 \\
\hline WRF & FIAVSIPLNYNRRQIDLRQLILISTTWIFAFAVASPVIFGLNNVPNRDPSLCQLEDDNYI & 60 \\
\hline SF & FIAVSIPLNYNRRQIDLRQLILISTTWIFAFAVASPVIFGLNNVPNRDPSLCQLEDDNYI & 60 \\
\hline LM & 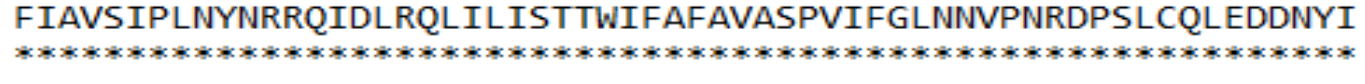 & 60 \\
\hline LF & VYSSICSFFIPCPVMLVLYCAMFQGLKRWEEARKAKLRGSIYGANRKLYHPSTFIEREQT & 126 \\
\hline SM & VYSSICSFFIPCPVMLVLYCAMFQGLKRWEEARKAKLRGSIYGANRKLYHPSTFIEREQT & 120 \\
\hline WRF & VYSSICSFFIPCPVMLVLYCAMFQGLKRWEEARKAKLRGSIYGANRKLYHPSTFIEREQT & $12 e$ \\
\hline SF & VYSSICSFFIPCPVMLVLYCAMFQGLKRWEEARKAKLRGSIYGANRKLYHPSTFIEREQT & 126 \\
\hline LM & 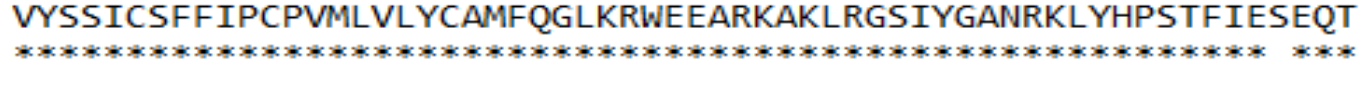 & 126 \\
\hline LF & GLEPEECGPYAHSSHPGDYVMNNGIPTVSYPHLKYPPPGHGRKRAKINGRERKAMRVLPV & 180 \\
\hline SM & GLEPEECGPYAHSSHPGDYVMNNGIPTVSYPHLKYPPPGHGRKRAKINGRERKAMRVLPV & 180 \\
\hline WRF & GLEPEECGPYAHSSHPGDYVMNNGIPTVSYPHLKYPPPGHGRKRAKINGRERKAMRVLPV & 180 \\
\hline SF & GLEPEECGPYAHSSHPGDYVMNNGIPTVSYPHLKYPPPGHGRKRAKINGRERKAMRVLPV & 180 \\
\hline LM & 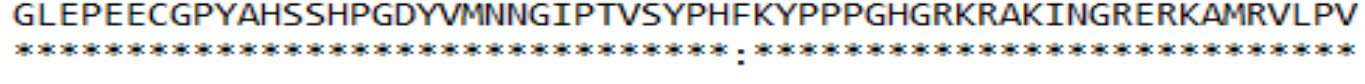 & 188 \\
\hline LF & 182 & \\
\hline SM & 182 & \\
\hline WRF & 182 & \\
\hline SF & 182 & \\
\hline LM & $\begin{array}{l}W \\
* * *\end{array}$ & \\
\hline
\end{tabular}

\section{Karyotype analyses}

The chromosome complement of of the three sexed pigeon breeds (racing long distances, short distances and non-racing wild rock pigeons ), is composed of 78 autosomes and a pair of sex Chromosomes ( $\mathrm{Z}$ and $\mathrm{W}$ ), thus making the diploid number of chromosomes, $2 \mathrm{n}=80$ (Table 5; fig 5). The relative length (RL \%), centromeric index (CI \%) and centromere position were estimated as displayed in Table (5) and figure (4).

In general, the morphological features of the chromosome complement of the three pigeons breeds were in accordance with the basic bird karyotype revealing the karyotype formula $2 \mathrm{n}=80=$

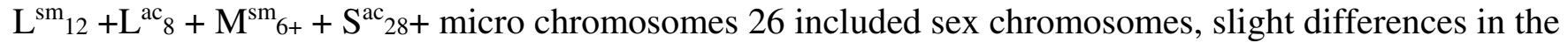
measured parameters were detected among the three pigeon breeds as shown in Table (5), and illustrated in the histograms (Figs. 3 and 4). 


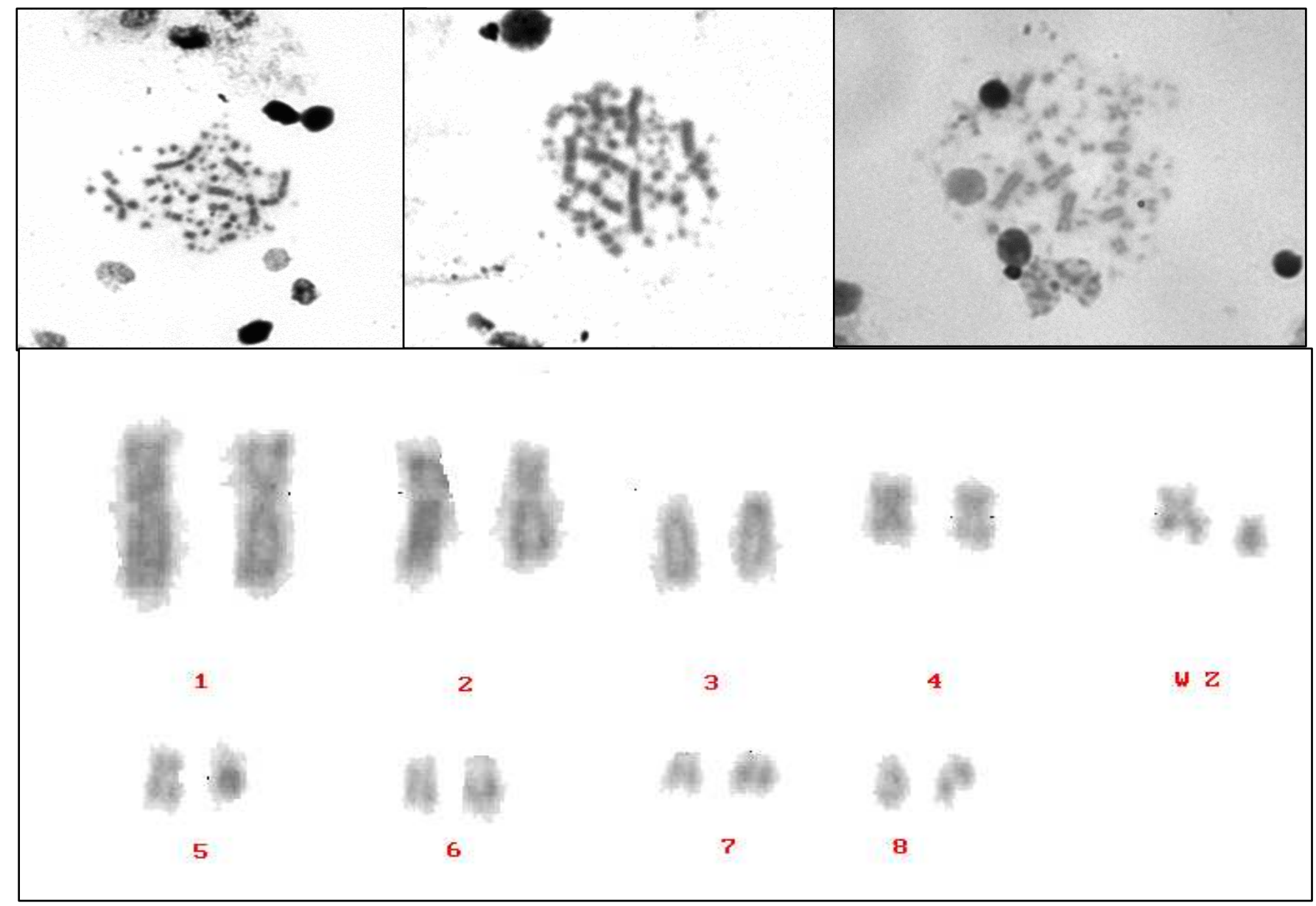

Fig. 2: Spread metaphase cells and male Karyotype of the three pigeon breeds.

Table (5): The relative length (RL \%), the centromere index (CI \%) and centromere position (CP) for the three pigeon breeds.

\begin{tabular}{|c|c|c|c|c|c|c|c|}
\hline \multirow{2}{*}{\multicolumn{2}{|c|}{ RL \% }} & \multicolumn{5}{|c|}{ CI } & \multirow[t]{2}{*}{$\mathbf{C P}$} \\
\hline & & 2 & 3 & 1 & 2 & 3 & \\
\hline 1 & 6.65 & 6.88 & 6.64 & 44.18 & 44.50 & 44.11 & submetcentric \\
\hline 3 & 4.98 & 5.33 & 5.24 & 3.03 & 3.23 & 3.33 & acrocentric \\
\hline 4 & 6.50 & 6.70 & 6.47 & 44.86 & 44.59 & 44.24 & submetcentric \\
\hline 6 & 6.34 & 6.19 & 6.29 & 4.86 & 4.44 & 4.44 & acrocentric \\
\hline 7 & 6.34 & 6.19 & 6.29 & 3.86 & 4.44 & 4.44 & acrocentric \\
\hline 8 & 6.04 & 6.02 & 6.12 & 3.90 & 3.86 & 3.86 & acrocentric \\
\hline $\mathbf{Z}$ & 3.29 & 3.27 & 3.15 & 44.86 & 44.37 & 44.44 & submetcentric \\
\hline
\end{tabular}




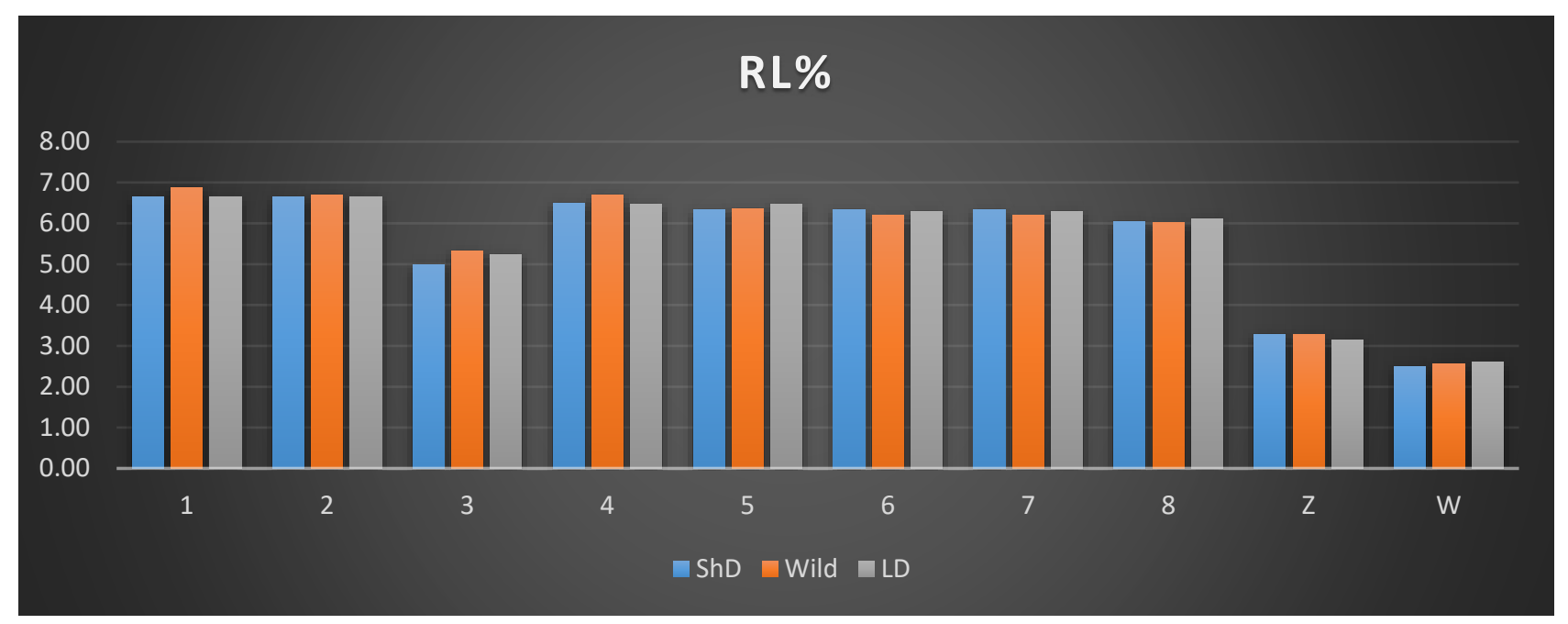

Fig.3: Histogram showing the relative length (RL \%) of the 8 autosomal pairs and the $\mathrm{Z}$ and $\mathrm{W}$ chromosomes in the three pigeon breeds.

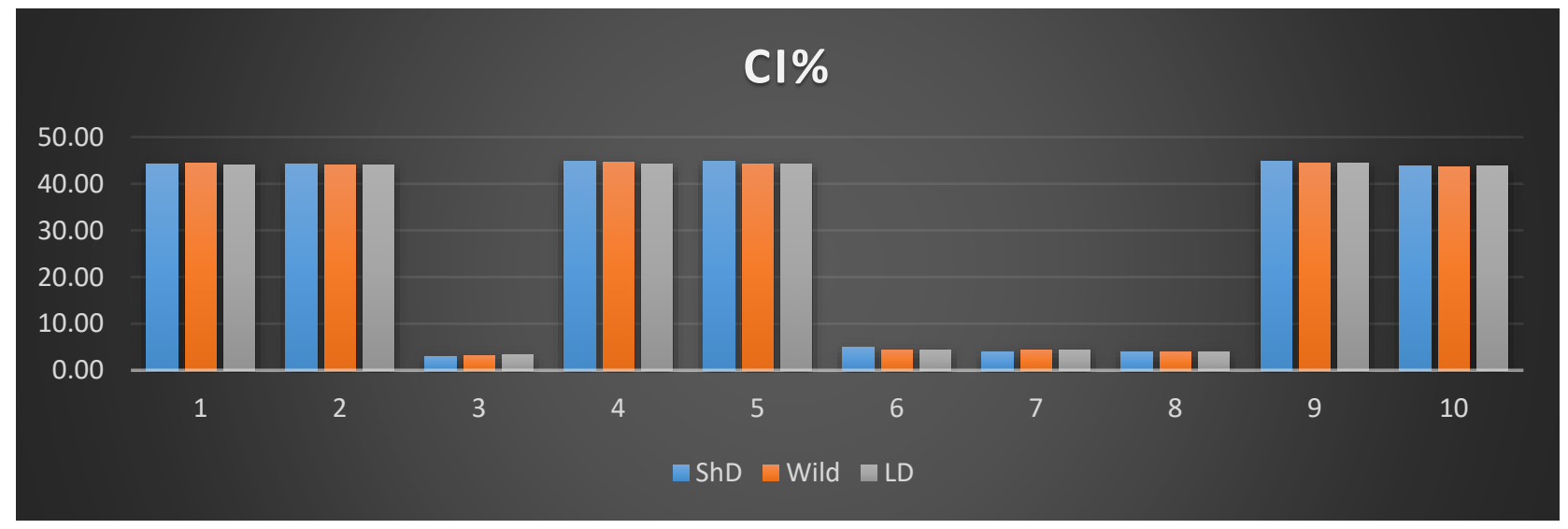

Fig.4: Histogram showing the centromere index (CI \%) of the 8 autosomal pairs and the $\mathrm{Z}$ and W chromosomes in the three pigeon breeds.

The relative length of the 38 autosomal chromosomes across the three pigeon breeds ranged from $6.88 \%$ (chromosome 1) to $4.98 \%$ (chromosome 3 ). The relative length of the longest chromosome (chromosome 1) in the pigeon breed of short distances, wild rock and long distances breeds was 6.65, 6.88 and $6.64 \%$, respectively. While, the shortest autosomal chromosome (chromosome 3) revealed a relative length of $4.98,5.33$ and $5.24 \%$ in the pigeon breed of short distances, wild rock and long distances breeds, respectively. Similarly, the three breeds revealed negligible differences in the relative length of the $\mathrm{Z}(3.29,3.27$ and 3.15\%) and $\mathrm{W}(2.50,2.56$ and $2.60 \%)$ chromosomes in the pigeon breed of short distances, wild rock and long distances breeds, respectively. These slight differences could be attributed to different levels of chromosome condensation among the three pigeon breeds.

The centromere index for the chromosomes of the three pigeon breeds are presented in Table (5) and illustrated as histogram in (Fig.3). The results confirmed the metacentric nature of the three longest chromosomes. The centromeric index for the longest chromosome (chromosome1) was 44.18, 44.50 and $44.11 \%$ for the pigeon breed of short distances, wild rock and long distances breeds, respectively, the centromeric index for the shortest chromosome was 3.03, 3.23 and 3.33 for chromosome 3 for the pigeon breed of short distances, Wild and long distances breeds, respectively. The rest of the autosomes 
were acrocentric with $0.0 \%$ centromeric index in the three breeds. In addition, the $\mathrm{Z}$ chromosome proved to be submetacentric with CI\% of $44.86,44.37$ and $44.44 \%$ for racing short distances, non-racing wild rock and racing long distances pigeon breeds, respectively and the $\mathrm{W}$ chromosome proved to be acrocentric with CI\% of 3.90, 3.72 and 3.80 for the pigeon breed of short distances, wild rock and long distances breeds, respectively.

\section{GTG-banding analysis}

The G-band idiogram of the chromosomes was developed based on twenty selected metaphases using automated karyotyping \& FISH software processing (Leica CW4000) as shown in fig. 2. Cytological examination of the G-banded chromosomes for the racing short distances, non-racing wild rock and racing long distances pigeon breeds revealed that the karyotype macrostructures were highly conserved and in general, in considerable accordance to the standard karyotype of to the standard of $G$ band identification on the chromosomes of Gallus domesticus (26).

The G-banding method using the photolytic enzyme trypsin affects the interaction that stabilises the structure of different proteins and nucleic acid components of the chromatin. Therefore, the G-band mechanism is based mainly upon differences in protein composition and organization (29 and 24). It has also been suggested that trypsin treatment leads to the unfolding of protein loops and permits the protein structure associated with the alignment of AT-rich sequences, as reported by (24).

8 pairs of autosomes and sex chromosomes were analyzed. The short arm (p) of the chromosomes ( 1 and 2) and the long arm (q) of the chromosomes 2 and 4 as well as sex chromosome Z were divided into two regions. Meanwhile, the long arm (q) arms of chromosomes 1 and 3 were divided into three regions, but (p) arms of chromosomes (4, 5 and sex chromosomes $\mathrm{Z}$ and $\mathrm{W}$ ) and (q) arms of chromosomes 6, 7 and 8 as well as sex chromosomes $\mathrm{W}$ observed into one region (fig. 5 ).

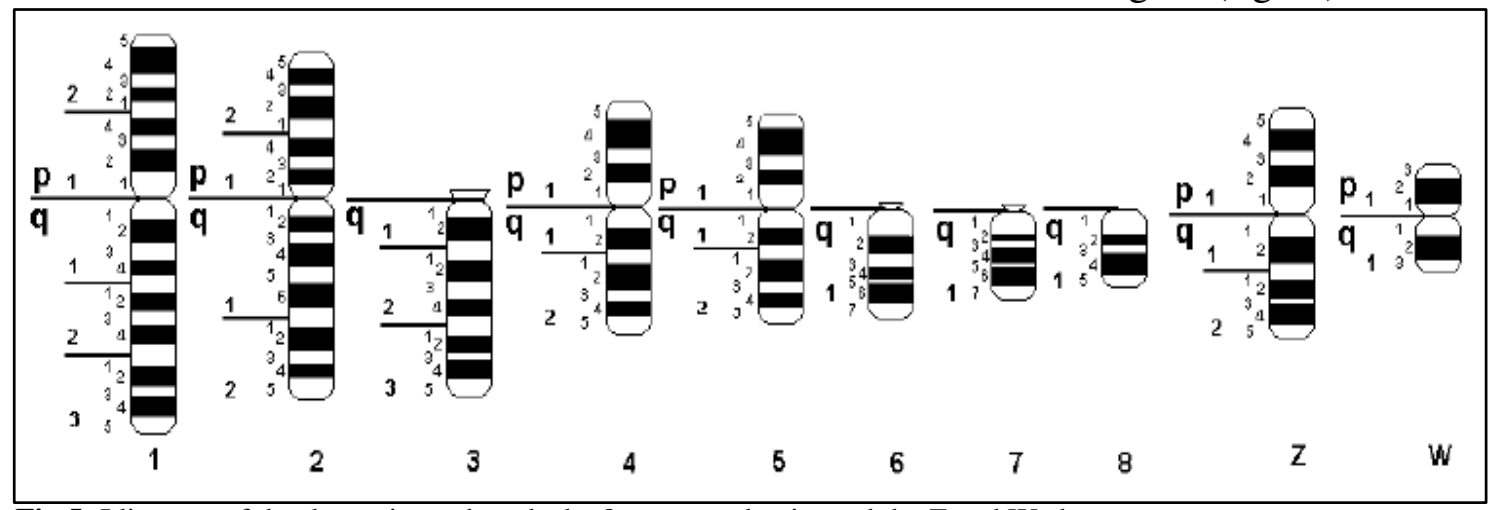

Fig.5: Idiogram of the three pigeon breeds the 8 autosomal pairs and the $\mathrm{Z}$ and $\mathrm{W}$ chromosomes.

The G- banded idiogram of each the three pigeon breeds comprised 114 bands in one set of haploid complement. The number of G-positive bands was 65, while, the total number of G-negative bands was 65 (Table 6).

Table (6): The total number of G- bands idiogram of 10 pairs of the three pigeon breeds, number of G-positive bands and Gnegative bands

\begin{tabular}{|c|c|c|c|c|c|}
\hline & & G-positive bands & G-negative bands & Total & \multirow{3}{*}{22} \\
\hline \multirow{2}{*}{1} & $\mathbf{p}$ & 4 & 5 & 9 & \\
\hline & $\mathbf{q}$ & 6 & 7 & 13 & \\
\hline \multirow{2}{*}{2} & p & 4 & 5 & 9 & \multirow{2}{*}{20} \\
\hline & q & 5 & 6 & 11 & \\
\hline 3 & p & 5 & 6 & 11 & 11 \\
\hline \multirow{2}{*}{4} & p & 2 & 3 & 5 & \multirow{2}{*}{12} \\
\hline & $q$ & 3 & 4 & 7 & \\
\hline
\end{tabular}




\begin{tabular}{|c|c|c|c|c|c|}
\hline \multirow{2}{*}{5} & p & 2 & 3 & 5 & \multirow{2}{*}{12} \\
\hline & $q$ & 3 & 4 & 7 & \\
\hline 6 & p & 3 & 4 & 7 & 7 \\
\hline 7 & $\mathbf{P}$ & 3 & 4 & 7 & 7 \\
\hline 8 & $\mathbf{p}$ & 2 & 3 & 5 & 5 \\
\hline \multirow{2}{*}{$\mathbf{Z}$} & $\mathbf{p}$ & 2 & 3 & 5 & \multirow{2}{*}{12} \\
\hline & $\mathbf{q}$ & 3 & 4 & 7 & \\
\hline \multirow{2}{*}{ W } & p & 1 & 2 & 3 & \multirow{2}{*}{6} \\
\hline & $q$ & 1 & 2 & 3 & \\
\hline Total & & 49 & 65 & 114 & \\
\hline
\end{tabular}

Twenty-two bands were detected in chromosome no. 1, nine bands were observed in the short arm, while, thirteen bands were observed in the long arm, while chromosome no. 2 were detected Twenty bands, nine bands were observed in the short arm and eleven bands were observed in the long arm. The same twelve bands were detected in chromosomes number (4, 5 and Z) and also observed five bands in the short arm and seven bands in long arm. While the acrocentric chromosome no. 3 were detect eleven bands and the acrocentric chromosome no. 8 were detect five bands but the two acrocentric chromosomes no. 6 and 7 were detect seven bands, but the W chromosome were detected 6 bands, three bands were observed in each two arms.

By utilizing the relative length, the centromere index and the G-banding for the 10 chromosome pairs of the three birds breeds (Tables 5 and 6), it was illustrated that, the three pigeon breeds chromosomes are basically highly similar.

\section{Neurotransmitters concentrations in brain tissues of pigeon breeds}

Differences in neurotransmitters concentrations in brain tissues of three pigeon breeds are presented in Table 7. The pigeon breed of long distances racing showed the highest concentration $(\mathrm{P}<0.001)$ in all measured neurotransmitters; dopamine (DA), serotonin (ST), gamma-aminobutyric acid (GABA), acetyl choline esterase (ACHE) and melatonin (MTN) in brain tissues. In contrast, wild rock pigeon showed the lowest concentration among pigeon breeds in all measured brain's neurotransmitters. No significant gender-related differences were observed in the three pigeon breeds and therefore, the data in males and females were presented as averages.

Table 7. Differences in Neurotransmitters; dopamine (DA), serotonin (ST), Gamma-aminobutyric acid (GABA), acetyl choline esterase (ACHE) and melatonin (MTN) in brain tissues of Pigeon breeds

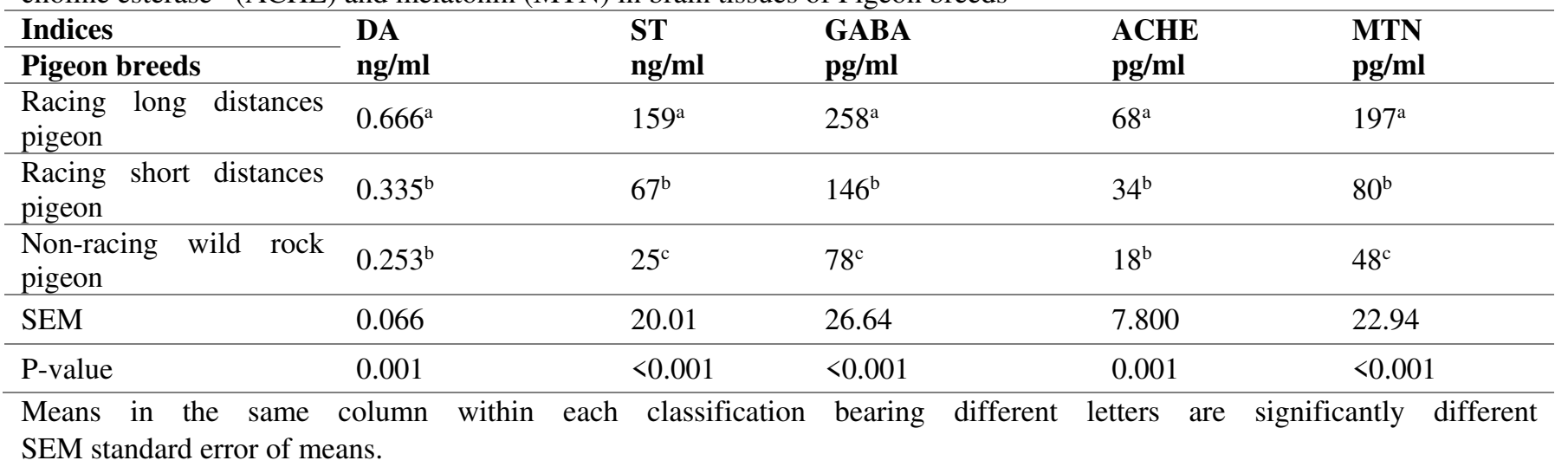




\section{DISCUSSION}

In this research work, the comparison of some neurotransmitters among three pigeon breeds; the nonracing wild rock pigeon and two racing pigeon breeds ( long distance fly over 500 mils vs short distance fly up to 500 miles ), showed that the pigeon breed of long distances racing showed the highest significant concentration $(\mathrm{P}<0.001)$ in all measured neurotransmitters including; DA, ST, GABA, ACHE and MTN in the brain tissues among other studied pigeon breeds (as seen in the result, Table 7), In contrast, the non-racing wild rock pigeon showed the lowest concentration in all measured brain's neurotransmitters. These results confirmed the important effects of brain neurotransmitters for high fly performance and home back in the racing competitions', particularly, in this breed that fly (>500 mile). The reason for this difference is unknown. However, in point view of authors, the highest elevation in neurotransmitters concentration in brain tissue of the pigeon breed of long distances racing may be indicate the best health status, healthy brain functions rich with neurons, performance, high genetic structure, brain development of this breed, and thus explain a better race performance of this breed to fly long distance and back home faster more than the pigeon breed of short distances racing and the wild rock pigeon, respectively. In spite of the information referring to neurotransmitters concentrations in brain tissues in different pigeon breeds to date are limited or missing, the analysis of neurotransmitters in the brain helps to understand brain function of pigeon breed and considering the fact that brain's neurotransmitters estimations have vital role in selecting racing pigeon breeders. Hence, the brain uses a variety of chemicals messengers called neurotransmitters to communicate between brain cells. Many studies showed the important part of neurotransmitters in the nervous system as they used to transmit many types of chemical messages" powerful neurochemicals or neurotransmitters " between neurons of pigeon brain cells at the synapse, or from the nerve cells to target tissue throughout the body such as, muscles, glands, or other nerves. They enable the brain to provide a variety of functions, through the process of chemical synaptic transmission. The brain needs neurotransmitters either excitatory or inhibitory to regulate many necessary bodily functions, including: heart rat, thinking and memory, breathing, sleep cycles, digestion, mood, concentration, appetite, muscle movement. The lack of these neurotransmitters associated with some diseases and brain injuries. Many searchers reported that having low levels of neurotransmitters levels in certain regions of the brain tissue and central nervous system may leading to various brain's diseases and major neurological disorders such as impaired motor coordination, learning and memory impairments, fatigue and muscle weakness, visual disturbances, cognitive impairment, hallucinations, depression and anxiety disorders (30 and 31). One of the neurotransmitters is DA which is important for memory formation, influence several brain functions, including learning, blood flow, behavior, responsible for muscle movement coordination abilities, reward, emotion, alertness, decision-making, stimulates the secretion of growth hormone and executive functions (14). The brain releases dopamine during pleasurable activities. GABA also, is a mood regulator and contributes to vision. It has an inhibitory action in the central nervous system, which stops neurons from becoming overexcited and essential for the memory-storage elements of the brain, lowers stress and anxiety by slowing down heart rate, body temperature, and blood pressure (15). While ST is an inhibitory neurotransmitter present in the brain and other tissues, particularly blood platelets "thrombocytes" and the lining of the digestive tract. In the brain, ST has been identified as an important factor in sleep cycle, helps regulate mood and emotions, metabolism and appetite, gut motility, blood clotting, perception of pain, body temperature, affect gastrointestinal processes like bowel motility, bladder control, the body's circadian rhythm, cardiovascular function and plays a role in depression and anxiety (16). Furthermore, more than $90 \%$ of the body's total serotonin resides in the enterochromaffin cells in the gut, where it helps regulate the movement of the digestive system. An insufficient secretion of serotonin may result in decreased immune system function, emotional disorders like depression and 
disorder. MTN is a tryptophan-derived substituted indoleamine,_acting as a neuromodulator, regulates various physiological processes, such as sleep wake cycle, seasonal adaptation and immune function (18 and 19). Acetylcholine is an excitatory neurotransmitter present in the brain secreted by motor neurons, critical for normal attention, memory, sleep cycle, stimulates muscle contraction, inhibit the heart muscle and controls the heartbeat. The low levels of ACHE in the brain can cause fatigue and muscle weakness. Thus, neurotransmitters play a role in nearly every function in the human body. A balance of neurotransmitters is necessary to prevent certain health conditions, such as depression, anxiety, neurological disorders and mental health (17). Concerning the genetic measures, the current study investigated also the degree of genetic polymorphism (as seen in the result, Table 4), and protein sequence(as seen in the result, Figure1 A and B), among three pigeon breeds by focusing on the genes encoding dopamine receptor D4(DR-D4) named "neurotransmitter-associated gene "that known to be associated with brain functions and the lactate dehydrogenase A (LDH-A) gene named "performance associated gene" which found predominantly in muscle tissues and known to be associated with pigeon racing performance. Taking into account the wild rock pigeon (Columba livia) consider the original genetic stock for the evolutionary of domesticated pigeons. The results clearly revealed major differences present between pigeon breeds in the DR-D4 and LDH-A genes polymorphism and protein sequence. Thereby, there were different biodiversity values for both genes among pigeon breeds particularly, between long distances male pigeon and both gender of wild rock pigeons, wherein, they showed high variation in genes polymorphism values, while the rest of breeds showed the same gene polymorphism. Furthermore, the variations appeared in LDH-A polymorphism of long distances male pigeon, particularly, on the position length $389 \mathrm{bp}$ or on two positions length of $418 \mathrm{bp}$ and $524 \mathrm{bp}$ for DR-D4 polymorphism indicate the presence of unique diversity in this breed, hence $A$ changed to $G$ for LDH-A and A changed to $\mathrm{C}$ and A changed to T for DR-D4 gene which means that high changes in gene expression occurred for both genes resulted in overall differences in the amino acids structure. The data derived from LDH-A gene protein sequence showed that in the position of 60 the amino acid K (lys) was converted to $\mathrm{E}$ ( $g l u$ ) in the LDH-A gene only in long distances male pigeon compared to the other breeds. while, DR-D4 gene protein sequence in the pigeon breeds showed also that in the positions of 117 and 153 the amino acid R (arg) and L (leu) were converted to S (ser) and F (phe) only in long distances male pigeon compared to the other breeds. In spite of all pigeon breeds used in this study were subjected to the same managements as well as feeding, the results of DR-D4 and LDH-A gene protein sequence particularly, in long distances male pigeon compared to the other breeds confirmed the important role of amino acids; glu for LDH-A gene, ser and phe for DR-D4 gene polymorphism, in addition to their role as a precursors for neurotransmitters building. Many studies have been reported the importance of amino acids such as phe, ser, glu, tryptophan, tyrosine, alanine, Isoleucine, leucine, valine and histidine which present in brain tissues with highest concentration. Theses amino acids are taken up in the body either from protein-rich diet or synthesized by phenylalanine hydroxylation. They indirectly modulating synthesis of catecholamines, ST, GABA, DA and histamine $(32,33,34,35,36$ and 37). To the authors' knowledge, less is known about the amino acids roles for brain functions, health and genes polymorphism in the pigeon breeds. Therefore, further work is necessary in this topic. The variations in the DR-D4 gene polymorphism and protein sequence might have role in increasing the levels of monoamines, particularly dopamine .whenever, the variations in the LDH-A gene polymorphism and protein sequence might have role in increasing the levels of fuel source of energy for muscular activity and consequently the pigeon fly performance. It is well known that, the DR-D4 gene of pigeon breeds affects the brain cells and enhances release of neurotransmitters such as ST and DA resulting in increased their levels within the synaptic cleft leads to induce temporary improvements in physical and brain functions, mood, then elevate the body's ability to regulate muscles 
movement resulting in a better performance and powerful (38). Hence, DR-D4 gene is associated with the levels of monoamines in pigeon racing. Also DR-D4 gene protein sequence showed changes in the expression of genes that regulate tryptophan hydroxylase, an enzyme involved in ST synthesis particularly in long distance male piegeon breed. In contrast, no changes in the expression of genes for protein sequence in the other breeds and thereby may be led to low DA and ST. These can be the possible reasons for poor memory and depressed mood, neurodegenerative disorder, depression, anxiety, and attention processes. the further results agree with (21) who showed a number of different variations in DR-D4 gene between two racing pigeon either fly short distances races $(<400 \mathrm{~km})$ or middle distances races $(>500 \mathrm{~km})$. They attributed the variances in speed and distance performance between two mentioned breeds at all distances (both middle and short distance), to the polymorphism in DR-D4 gene. The variations in this gene has been associated with mental capabilities and performance of racing pigeon (39 and 40). Regarding, the results of LDH-A gene polymorphism and protein sequence, (21 and 5) showed the efficiently of LDH-A genes in recycling and reusing the lactate in the muscles and consequently, leads to better speed performance (41). Many studies showed that lactate is considered as an important fuel source of energy for muscular activity during strong exercises and racing competitions when oxygen is absent or in short supply and the rate of demand for energy is high; LDH-A enzyme converts pyruvate, the final product of glycolysis to lactate with nicotinamide adenine dinucleotide as a coenzyme (2). Additionally, (8, 1, 42 and 43) attributed the racing pigeon survivability and homing abilities during racing the competitions to LDHA gene polymorphism and its role in physical and mental performance. From the previous results, testing the racing pigeon breeds for both LDHA the DRD4 genes is important process in selecting new pigeon breeders and breeding perfect champion racing pigeons with high quality racing performance, capable of long flights and rapid return from distant released places through carrying possible variations of these genes and exclude the other pigeons not carry at least one of the these racing performance genes from breeding program. With the Baladi breed, intron 1, exon 1; and with the Damascus breed, intron 2, part of exon 3 with the bioinformatics tools, Egyptian goat breeds consider national wealth can be used to build breeding and improvement programmes that help in more applicable scopes such as biotechnology, genetic engineering, and molecular biology (44). Another indices studied in the current study and may be important in selecting racing pigeon breeds is cytogenetic indices including; chromosome structure and the precise identification of chromosomes using differential staining techniques such as G-banding and establishing a standard chromosome nomenclature for each breed. But, the study showed slight differences in the measured parameters of cytogenetic indices (the relative length, the centromere index and the G-banding for the 10 chromosome pairs), were detected among the three pigeon breeds. Therefore, form the above results discussed, the mentioned genes polymorphisms and their protein sequence ascertained the important role of neurotransmitters in selecting best racing pigeons breeders. Taking also into account there were a slight differences in the measured parameters of cytogenetic indices were detected among the three pigeon breeds.

\section{CONCLUSION}

In this article, It can be concluded that the values of both DR-D4 and LDH-A gene polymorphism and their protein sequence and neurotransmitters estimation in the brain tissue of pigeon would be useful indices for the differentiation and genetic characterization of racing pigeon breeds and provide a foundation for developing sustainable genetic improvement and conservation programs of the breeding and selecting racing pigeons breeders. 


\title{
ACKNOWLEDGMENT
}

The authors also would like to express sincere thanks and deep appreciation to the National Gene Bank, Animal Genetic Resources Dept., Agric. Res. Center, Giza, Egypt, and the Biological Application Department, Nuclear Research Center, Egyptian Atomic Energy Authority, for their cooperation. The authors are grateful to Dr. Neveen Abdel Fattah Director, National Gene Bank- Egypt to support this article. Also, the authors are grateful to Dr. Wakwak, Mohamed Magda who assisted and provided advice in the production of this article.

\section{AUTHORS' CONTRIBUTIONS}

NSI, NA and AEA participated in pigeon breeds sample collection and performed three breeds of Pigeons (racing pigeon's long distances i.e Gan aarden breed, racing pigeon's short distances i.e. Gansen breed and non-racing wild rock pigeons), maintained at the pigeons experimental farm and the statistical analysis of neurotransmitters data. NSI, nashaat1977@yahoo.com, Co-Author, participated in the conception, the design, data collection, interpretation of the results, wrote the manuscript and acted as corresponding author with MAE. Data discussion, data analyses. MAE, WSM and HAMA participated in genetic analyses of breeds (racing pigeon's long distances i.e Gan aarden breed, racing pigeon's short distances i.e. Gansen breed and non-racing wild rock pigeons) and the data discussion and data analyses, and MEA, MAI measured parameters of cytogenetic among the three pigeon breeds and the data discussion and data analysis. The authors read and approved the final manuscript.

\section{CONFLICT OF INTEREST}

The authors declare that they have no conflict of interest.

\author{
Abbreviations \\ LM; males racing pigeon's long distances, \\ LF; females racing pigeon's long distances, \\ SM; males racing pigeon's short distances, \\ SF; females racing pigeon's short distances, \\ $\mathrm{WM}$; males wild rock pigeons, \\ WF; females wild rock pigeons, \\ $\mathrm{K}($ lys $)$; Lysine, \\ E (glu); Glutamic acid, \\ $\mathrm{R}$ (arg); Arginine, \\ $\mathrm{S}$ (ser); Serine, \\ $\mathrm{F}$ (phe); Phenylalanine and \\ L (leu); Leucine.
}

\section{REFERENCES}

1. Ramadan S, Yamaura J, Miyake T, Inoue-Murayama M. DNA polymorphism within LDH-A gene in pigeon (Columba livia). J Poult Sci.; 50: 194-197. (2013a)

2. Ramadan S, Junichi Yamaura, Takeshi Miyake, Miho Inoue-Murayama . DNA Polymorphism within LDH-A Gene in Pigeon (Columba livia). Journal of Poultry Science. 50 (3): 194-197. doi:10.2141/ jpsa.0120137.(2013)

3. Proskura WS, Daria Cichoń, Wilhelm Grzesiak, Daniel Zaborski, Ewa Sell-Kubiak, YeongHsiang Cheng and Andrzej Dybus. Single Nucleotide Polymorphism in the LDHA Gene as a Potential Marker for the Racing Performance of Pigeons. Journal of Poultry Science. 51 (4) 364368, doi:10.2141/ jpsa.0130237 (2014) 
4. Michael D, Shapiro , Eric T, Domyan. Domestic pigeons. Curr Biol. 23(8): R302-R303. doi:10.1016/j.cub..01.063.(2013)

5. Hunnam J C, Sloan S, McCowan CI, Glass E, Walker C. The racing pigeon (Columba livia domestica) industry in Victoria, Australia, and epidemiology of a novel Group A rotavirus outbreak. Transbound Emerg Dis. 66:2058-2066. (2019)

6. Coulter TJ. et al. IJSEP. Doi: 10.1080/1612197X. 2015.1016085. (2015)

7. Allen MS, Laborde S. Curr Dir Psychol Sci, 23: 460-465. (2014)

8. Dybus A, Pijanka J, Cheng Y-H, Sheen F, Grzesiak W, Muszyńska M. Polymorphism within theLDHA gene in the homing and non-homing pigeons. J Appl Genet. 47: 63-66. https://doi.org/10.1007/ BF03194601. (2006)

9. Kersting C, Agelopoulos K, Schmidt H, Korsching E, August C, Gosheger G, Dirksen U, Juergens H, Winkelmann W, Brandt B, Bielack S, Buerger H, and Gebert C. Biological Importance of a Polymorphic CA Sequence within Intron 1 of the Epidermal Growth Factor Receptor Gene (EGFR) in High Grade Central Osteosarcomas. Genes, Chromosomes \& Cancer, (47): 657-664. (2008)

10. Hejjas K, Kubinyi E, Ronai Z, Szekely A, Vas J, Miklosi AM, Sasvari-Szekely M and Kereszturi E. Molecular and behavioral analysis of the intron 2 repeat polymorphism in the canine dopamine D4 receptor gene. Genes, Brain and Behavior, ( 8): 330-336. (2009)

11. Cuyas E, Robledo P, Pizarro N, et al. 3,4-methylenedioxymethamphetamine induces gene expression changes in rats related to serotonergic and dopaminergic systems, but not to neurotoxicity. Neurotox Res. 25(2):161-169. doi:10.1007/s12640-013-9416-1. (2014)

12. Balestri M. et al. Int Clin Psychopharmacol. 29: 1-15. (2014)

13. Rangel-Barajas C, Coronel I, Florán B, Dopamine Receptors and Neurodegeneration. Aging Dis . 2015 1;6(5):349-68. doi: 10.14336/AD. 0330. eCollection 2015 Sep. (2015).

14. Rizo J, Mechanism of neurotransmitter release coming into focus. Protein Sci. 27(8):1364-1391. doi: 10.1002/pro.3445. Epub 2018 Jul 10. (2018)

15. Bowery NG, Smart TG. GABA and glycine as neurotransmitters: a brief history. Br J Pharmacol. 147 Suppl 1:S109-19. (2006)

16. Berger M, Gray JA, Roth BL. The expanded biology of serotonin. Annu Rev Med. 60:355-66. (2009)

17. Südhof TC. Neurotransmitter release: the last millisecond in the life of a synaptic vesicle. Neuron; 30;80(3):675-90. (2013)

18. Huang H. Wang Z, Weng SJ, Sun XH, Yang X. Neuromodulatory role of melatonin in retinal information processing. Prog. Retin. Eye Res. 32: 64-87. (2013)

19. Reiter RJ, Mayo JC, Tan DX, Sainz RM, Alatorre-Jimenez M, Qin L. Melatonin as an antioxidant: Under promises but over delivers. J. Pineal Res. 61: 253-278. (2016)

20. Proskura WS, Kustosz J, Dybus A, Lanckriet R. Polymorphism in dopamine receptor D4 gene is associated with pigeon racing performance. Animal Genetics. 46(5):586-7. doi: 10.1111/age. (2015)

21. Sambrook J, Fritschi EF and Maniatis T, Molecular cloning: a laboratory manual, Cold Spring Harbor Laboratory Press, New York .(1989)

22. Madeira F, Park YM, Lee J, Buso N, Gur T, Madhusoodanan N, Basutkar P, Tivey ARN, Potter SC, Finn RD, Lopez R. The EMBL-EBI search and sequence analysis tools APIs in 2019. Nucleic Acids Res, 47(W1), W636-W641. DOI: 10.1093/nar/gkz268, EuropePMC: 30976793.(2019)

23. Dos Santos MdS, Kretschmer R, Furo IdO, Gunski RJ, del Valle Garnero A, Valeri MP, et al. Chromosomal evolution and phylogenetic considerations in cuckoos (Aves, Cuculiformes, Cuculidae). PLoS ONE . 15(5): e0232509. (2020) 
24. Abd El-Gawad Mona E, El-Itriby Hanaiya A, Sobhy MH, Hussein Ebtissam A. Fish- Mapping and Standard Gtg-Banding Karyotype Of Three Egyptian Sheep Breeds. Int. J. Adv. Res. 7(4):374-387.(2019)

25. Fechheimer NS. Chromosomes of Chickens Advances in Veterinary Science and Comparative Medicine. 34:169-207. (1990)

26. Ladjali-Mohammedi KA , Bitgood JJB, Tixier-Boichard MA, Ponce de Leon FAC. International System for Standardized Avian Karyotypes (ISSAK): standardized banded karyotypes of the domestic fowl (Gallus domesticus), Cytogenet Cell Genet. 86:271-276. (1999)

27. Manikkoth S, Deepa B, Sequeira M, Joy AE, Rodrigues R. Assessment of brain dopamine levels to evaluate the role of Tylophora indica ethanolic extract on alcohol induced anxiety in Wistar albino rats Journal of Young Pharmacists. 8(2): 91-95. (2016)

28. SPSS Inc. Program. User guide for personal computer statistics. Ver. 18.0. IBM Corp, Armonk. (2010)

29. Ali A, Babar ME, Mahmood S, Imran M. First report of GTG-banded nomenclature of Pakistani Lohi sheep (Ovis aries). Turk. J. Vet. Anim. Sci., 35: 213-217. (2011)

30. Pearl PL. Monoamine neurotransmitter deficiencies._ Handb Clin Neurol. 113:1819-25. doi: 10.1016/B978-0-444-59565-2.00051-4. PMID: 23622404. (2013)

31. Mastrangelo M. Epilepsy in inherited neurotransmitter disorders: Spotlights on pathophysiology and clinical management. Metab Brain Dis. 2021;36(1):29-43. doi: 10.1007/s11011-020-00635x. Epub Oct 23. PMID: 33095372. (2020)

32. Fernstrom, J.D.; Fernstrom, M.H. Tyrosine, phenylalanine, and catecholamine synthesis and function in the brain. J. Nutr. 137, 1539S-1547S. (2007)

33. Featherstone DE. Intercellular glutamate signaling in the nervous system and beyond. ACS Chem. Neurosci. 1: 4-12. (2010)

34. Coppola A, Wenner BR, Ilkayeva O, Stevens RD, Maggioni M, Slotkin TA, Levin ED, Newgard CB. Branched-chain amino acids alter neurobehavioral function in rats. Am. J. Physiol. Endocrinol. Metabol. 304: E4051-E4130. (2013)

35. LaNoue KF, Berkich DA, Conway M, Barber AJ, Hu LY, Taylor C, Hutson S. Role of specific aminotransferases in de novo glutamate synthesis and redox shuttling in the retina. J. Neurosci. Res. 66: 914-922. (2013)

36. Zhou Y, Danbolt NC. Glutamate as a neurotransmitter in the healthy brain. J. Neural Transm. 121: 799-817. (2014)

37. Dalangin, R, Kim A, Robert E. Campbell. The Role of Amino Acids in Neurotransmission and Fluorescent Tools for Their Detection. International Journal of Molecular Sciences. 21: 6197; doi:10.3390/ijms21176197.(2020)

38. Coyne SP, Stephen G, Clemente LJ, Barr CS, Parkerd KJ, Maestripieri D._Dopamine D4 receptor genotype variation in free-ranging rhesus macaques and its association with juvenile behavior Behav Brain Res. 1: 292: 50-55. doi:10.1016/j.bbr.2015.06.014.(2015)

39. Hua P, Liu W, Chen D, Zhao Y, Chen L, Zhang N, Wang C, Guo S, Wang L, Xiao H, et al. Cry1 and Tef gene polymorphisms are associated with Major Depressive Disorder in the Chinese population. J. Affect. Disord. 157: 100-103. (2014)

40. Shao Y, Tian H.Y, Hang J.J, Kharrati-Koopaee H, Guo X, Zhuang XL, Li ML, Nanaie HA, DehghaniTafti E, Shojaei B, et al. Genomic and Phenotypic Analyses Reveal Mechanisms Underlying Homing Ability in Pigeon. Mol. Biol. Evol. 37: 134-148. (2020)

41. Proia P, Di Liegro CM, Schiera G, Fricano A, Di Liegro I. Lactate as a metabolite and a regulator in the central nervous system. Int J Mol Sci. 17: 1450. (2016) 
42. Ramadan S, Miyake T, Yamaura J, InoueMurayama M. LDHA gene is associated with pigeon survivability during racing competitions. PLoS ONE , 13(5): e0195121. https://doi.org/. (2018)

43. Gazda MA, Andrade P, Afonso S, Dilyte J, Archer J.P, Lopes RJ, Faria R, Carneiro M. Signatures of Selection on Standing ' Genetic Variation Underlie Athletic and Navigational Performance in Racing Pigeons. Mol. Biol. Evol. 35: 1176-1189. (2018)

44. Dowidar Y.A., M.A. El-Sayed, Aly M. Elrefy, Hytham E. Shoura. Detection of myostatin gene MSTN in some goat breeds (Capra hircus). Journal of Genetic Engineering and Biotechnology (16)507-512 https://doi.org/10.1016/j.jgeb.2018 .04.002. (2018).

45. Fahmy et al. Evaluation of the Quality for the Egyptian Red Sea Coastal Waters during 2011-2013. Journal of Environmental Protection, 7, 1810-1834. DOI: 10.4236/jep.2016.712145. (2016)

46. Percie du Sert, N. et al. Reporting animal research: Explanation and elaboration for the ARRIVE guidelines 2.0. PLoS Biol 18(7): e3000411. https://doi.org/10.1371/journal.pbio.3000411 (2020). 